\title{
THE REVIEW OF MEETINGS OF THE GOVERNMENT OF THE RUSSIAN FEDERATION IN MAY 2015
}

\author{
M.Goldin
}

In May 2015, at the meetings of the Government of the Russian Federation among other things the following issues were discussed: a draft law in the sphere of mandatory social insurance against industrial accidents and occupational diseases; draft amendments to the Federal Law on Customs Regulation.

On 14 May, at the meeting of the Government of the Russian Federation among other issues the draft federal law on Amendment Some Legislative Acts of the Russian Federation as Regards Upgrading of the Legislation in the Sphere of Mandatory Social Insurance against Industrial Accidents and Occupational Diseases was discussed.

According to the concept of the architects of the draft law, the latter should unify the legal regulations in the area of mandatory social insurance against industrial accidents and occupational diseases, as well as such legal rules of other types of mandatory social insurance as regulate similar legal relations.

In particular, the concept of the definitions - "an insurance event" and "occupational diseases" - is brought in compliance with Federal Law No. 125-FZ of 24 July 1998 on Mandatory Social Insurance against Industrial Accidents and Occupational Diseases. So, the title to insurance reimbursements is granted in case of the death of the insured and not only in case of health injury.

The definition "the income of the insured" has been formulated anew: in calculation of the amount of the income lost by the insured as a result of occurrence of the insurance event, payments and other remunerations made in favor of individuals under civil law contracts on fulfilment of jobs and rendering of services and commissioning contracts under which the ordering customer is obligated to pay insurance contributions to the insurer are taken into account.

The norms regulating the determination of the amount of the income lost by the insured as a result of occurrence of the insurance event are specified in the draft law. The minimum wage amount set by the federal law as of the day of application for the assigned insurance benefit is introduced as the minimum social guarantee.

The architects of the draft law explain that by the fact that under the Labor Code of the Russian Federation in case of a health injury or death of the worker as a result of an industrial accident or occupational disease the lost income (earnings) is indemnified to the worker (his family). The amendment in question does not concern calculation of monthly insurance payments.

The draft law was approved at the meeting of the Government of the Russian Federation and submitted to the State Duma of the Russian Federation.

On 21 May 2015, at the meeting of the Government of the Russian Federation draft Federal Law on Amendment of Part 1 of Article 131 of the Federal Law on Customs Regulation in the Russian Federation was discussed.

In the existing version of the Federal Law on Customs Regulation in the Russian Federation, it is established that customs duties for activities related to release of goods are not charged in respect of cash currency (except for commemorative coins) of the Customs Union member-states imported or exported by central banks of those states.

According to the draft law, activities related to release of goods, cash currency of the Customs Union member-states, foreign currency (except for numismatic purposes), as well as issued securities are exempted from customs duties.

The draft law was approved at the meeting of the Government of the RF and submitted to the State Duma of the RF. 